\title{
ECONOMIC AND LEGAL CHARACTERISTICS OF FACTORING OPERATIONS IN UKRAINE
}

\author{
Petro Nemesh ${ }^{1}$ \\ Transcarpathian Qualification and Disciplinary Commission of the Bar, Ukraine
}

\author{
Iryna Nesterova², Vasil Fennych ${ }^{3}$ \\ Uzhhorod National University, Ukraine
}

\begin{abstract}
The objective of the article is to determine the economic and legal aspects of factoring operations in Ukraine, to disclose the specificity of the legal regulation mechanism of factoring operations, and to determine the peculiarity of economic activities financing with the help of factoring. The subject of the study is the Ukrainian experience in the formation and development of factoring activity. Methodology. The research is based on the historical and comparative method, with the help of which the study of the introduction of factoring in Ukraine is made. The analysis determines the reasons for the lack of development of classical factoring in Ukraine, where legal constructs of factoring operations do not correspond to the economic substance of this type of financial activity. On the basis of the comparative legal analysis, there are determined countries with classical factoring markets and the largest amount of working capital. The results of the study point out the construction preventing reasons of the classic factoring market in Ukraine, aimed at the development of small- and medium-sized businesses. They are related to not only the drawbacks of domestic legislation and practice of its application but economic factors as well. Factoring companies have weak financial potential and no substantive financial amounts since accounts receivable are financed by companies at their own expense. Funds request from bank loans or other borrowed funds for these purposes decreases annually. Practical implications. The positive experiences of the classical factoring market abroad demonstrate that for the implementation of classical factoring market, cheap loans or means of currency issuing for securities (such as bonds) should be available. Moreover, the proper implementation by the law enforcement authorities of the decree on debt collection from the debtor should be ensured, as it reduces the risk to the factor. This makes the search for non-traditional ways of guaranteeing the restitution of funded accounts receivable unnecessary. Originality. The comprehensive analysis of the factoring market state in Ukraine, its legal and economic aspects are the basis for developing the most promising directions of domestic civil legislation progress in the field of factoring activity.
\end{abstract}

Key words: factoring operation, economic-legal analysis, factoring agreement, accounts receivable.

JEL Classification: D02, P51, F53

1. Exposition of the problem and its connection with important scientific and practical tasks

Accounts receivable may prove to be a serious test for an enterprise delivering goods or providing certain services, the successful overcoming of accounts receivable will depend on the professionalism of the decisions taken. In some cases, external factors (inflation, credit risks, country's domestic policy, foreign economic factors, etc.) may affect these decisions, which lead to impairment of deferred payments; in turn, it may cause significant damage to the enterprise up to its bankruptcy.
Accounts receivable increases in Ukraine yearly, forcing companies to look for solutions for the working capital shortage. One of the financial tools for a solution is factoring operations, which allow the enterprise to receive money immediately after the delivery of goods (or services). The main benefit is no waste of time for completion of deferred payment. N.M. Shevchenko and G.V. Kravchenko underline occurrence of factoring in domestic economic for a good reason. There were objective prerequisites: a deterioration of payments state, solvency decrease, and the growth of economic entities debts (Levchenko, Kravchenko, 2009).

\footnotetext{
Corresponding author:

${ }^{1}$ Transcarpathian Qualification and Disciplinary Commission of the Bar.

${ }^{2}$ Department of Criminal Law and Criminal Process, Uzhhorod National University.

${ }^{3}$ Department of Civil Law and Process, Uzhhorod National University.
} 
Acquisition with the help of the factoring institute of accounts receivable in Ukraine has a number of significant drawbacks that lead to failure of the factoring market developing in our country. The analysis of these drawbacks will help to understand the situation in this sphere (on the example of Ukraine) of the financial services market and to outline ways for solving this problem.

Analysis of the latest research and publications. Investigations in the sphere of the factoring market and its legal implementation were to the greater extent made by economists than lawyers. Economists have analysed the economic substance of factoring operations (T.M. Holyk ta L.O. Matviichyk, A.D. Mineev, L.V. Nederia, etc.) while lawyers have revealed the peculiarity of factoring operations' legal support (I. Bezklubyi, K.D. Gasnikov, A.O. Zghama, A. Tokunova, Ya.O. Chapichadze, etc.)

Statement of the article's task. The objective of the article is to determine the economic and legal aspects of factoring operations in Ukraine, to disclose the specificity of the legal regulation mechanism of factoring operations, and to determine the peculiarity of economic activities financing with the help of factoring.

\section{Presentation of the main research material with a new substantiation of the scientific results obtained}

Nowadays commodity relations cannot exist without a loan. The result of crediting is the transfer of values from one business entity to another extended until the moment of obtainment of the equivalent. Such relationships relate to the deferral or instalment payment by the debtor due to goods transferred in his favour, performed work or rendered services. The result of this type of relationship is the occurrence of a monetary obligation between economic entities. The obligation may be implemented after the expiry of the prescribed period. The claim right that has arisen from the creditor to the debtor may have an independent worth and to become factoring agreements subject (Zavhorodnii, 2005).

This is unacceptable for the subject of entrepreneurial activity not to pay for the delivered goods (performed work, rendered service). Frozen assets do not facilitate commercial circulation in no way and, therefore, they have to attain a material worth. Thereby, their material worth would be included in the turnover. This became a precondition of legal institutes occurrence aimed at the inclusion of accounts receivable in contractual transactions (Iuhas, Popovych, 2015). One of such legal institutes became the institute of factoring agreement. It is proverbially that civil and economic-legal treaties serve as a legal form of mediation of economic relations. From the legal point of view, factoring operations are regulated by the Civil Code of Ukraine and the Commercial Code of Ukraine. Moreover, determining the general conditions and the order of concluding factoring agreement is provided by the Civil Code (Part 2 of Article 350 of the Civil Code of Ukraine) (Commercial Code of Ukraine: Law of Ukraine No. 436-IV of January 16, 2003), which contains chapter devoted to the factoring agreement (Chapter 73), as well as the rights and obligations of the parties to this contract and their responsibility (The Civil Code of Ukraine: Law of Ukraine No. 435-IV of January 16, 2003). Due to the fact that factoring operations are a kind of financial services provided by banks or other financial institutions, the legislative regulation of factoring transactions is also executed by the Law of Ukraine "On Financial Services and State Regulation of Financial Services Markets", which includes factoring to financial services (Item 11 Part 1 of Article 4) (On Financial Services and State Regulation of Financial Services Markets: Law of Ukraine No.2664-III dated July 12,2001), and the Law of Ukraine "On Banks and Banking", which defines factoring as a lending operation. (Item 3, Part 1 of Article 49) (On Banks and Banking: Law of Ukraine No. 2121-III dated December 7, 2000). The fact that factoring operations simultaneously belong to different types of operations is contradictory in the normative regulations. Thus, the Commercial Code of Ukraine refers factoring to banking operations (Article 339), while Civil Code of Ukraine determines the factor (funding source) as the bank or another financial institution, which has the authority to exercise factoring transactions (Part 3 of Article 1079). The contradiction between civil and economic regulation of the same legal institutes is traditional for domestic legislative practice. However, for the successful development of the factoring market in Ukraine, it would be efficient to develop a single normative act. And so, with the help of this act, Ukrainian legislation would determine the economic and legal peculiarities of the factoring operations' development.

As far as factoring services are provided when the company is experiencing a shortage of working capital and, as a rule, small and medium-sized enterprises in the light industry (food, printing, pharmaceutical, agricultural, etc.) conclude factoring agreement. Since big business does not experience financial difficulties due to funds from other activities and greater availability of bank loans. Although, factoring has a number of significant advantages (comparing to crediting):

1) debt repayment is carried out of funds, which in exceptional cases are received from the debtors, and from working capital of the client, while bank crediting repayment is carried out of working capital of the client; 2) factoring can be unlimited, while the loan is granted for a specified period, and its prolongation requires a rather complicated procedure of adjustment with the bank;

3) there are no costs for deposit insurance while factoring, and the loan is provided for collateral in the form of a pledge, guarantees, and bail;

4) the simplified package of documents is required for factoring processing; 
5) the received funds are used by the client on his own, while the crediting funds may be used exclusively for the purposes specified in the credit agreement;

6) using factoring, the $c$ lient can receive a number of additional services from the bank;

7) the financing amount depends on the amount of accounts receivable, while the loan amount depends on such factors as overpast income on the current account, security available, bank debt, etc. (Ruda).

In spite of such significant advantages, there is no developed classic factoring in Ukraine. Thus, classical factoring operation occurs when the bank or other financial institution that has the right to carry out factoring transactions (factor) provides the client with a financing fee (usually up to 120 days) in exchange for the client's concede of claim rights to the debtors (which have arisen out of delivery contracts, services provision, etc.) in favour of the factor. In exchange for the claim right to accounts receivable, factor immediately pays an advance to the client. The advance usually takes up to $90 \%$ of the ceded obligations' worth, and the rest of the amount is returned after the corresponding payments from the debtor are received. Factors' services are paid at the expense of the commission for the financing or other payments' provision, as well as interest per annum for the use of money (Sambirskyi). British economists M. Foreman, J. Gilbert, and F. Seelinger define "true" factoring as an open full-service agreement, which includes financing, credit risk insurance, debt collection, and other non-recourse services. Other factoring types are only its distortions and in fact cannot be considered as factoring, they believe. While M. Bikers defines factoring as a long-term agreement between a factoring company and a supplier who sells goods under commodity credit. And factor is obliged to buy accounts before they are received. And additionally, depending on the agreement, the factor is obliged to provide services such as keeping a debtors' book and administration of accounts receivable, debt collection, protection against losses in case of bad debts that may arise during buyers' bankruptcy (Palchuk, 2010).

While in Ukraine, factoring is considered as transactions, in which a bank or other financial institution that has the right to provide factoring services repurchases accounts receivable from another bank or a credit institution and afterwards independently collects debt from the debtor. Such contracts are concluded to get rid of problem accounts receivable, to repurchase own loan from the bank or other purposes related to valuable assets transfer. In the current economic situation that has developed over recent years, most of the factoring agreements belong exactly to this type. These operations, as the chief of the Association of Ukrainian factoring companies "UKRFAKTOR" notes, is not a factoring in the classical meaning of this concept (Sambirskyi). But their utilization is not limited by Ukrainian legislation.
According to Part 1 of the Article 1077 of the Civil Code of Ukraine under factoring agreement (financing under the cession of the monetary claim right), one of the parties (a factor) shall transfer or be obliged to transfer the funds into disposition of the other party (a client) for a fee, and a client shall cede or be obliged to cede a factor his right of the monetary claim to the third person (a debtor). A client may cede the factor his monetary claim to a debtor aimed at providing for the fulfilment of the client's obligation to a factor. The parties to the factoring agreement are the factor and the client. A factor may be a bank or other financial institution, which has the right to perform factoring operations. While a client to the factoring agreement may be a physical person or a legal entity, an economic agent (Article 1079 of the Civil Code of Ukraine), that is, it could be the bank itself, which has problem loans. Although, according to provisions of the international convention UNIDROIT "On International Factoring" (Ukraine joined in 2006 (About Ukraine's accession to the UNIDROIT Convention on International Factoring: Law of Ukraine No. 3302-IV dated 11th of May, 2006)), the supplier may or will assign to the factor receivables arising from contracts of sale of goods made between the supplier and its customers (debtors) other than those for the sale of goods bought primarily for their personal, family or household use (Item "a" of Part 2). Under this Convention, a transaction is factoring if it meets at least two of the following conditions: finance for the supplier, including loans and advance payments; maintenance of accounts (ledgering) relating to the receivables; collection of receivables; protection against default in payment by debtors (Item "b" of Part 2) (About International Factoring: UNIDROIT Convention of May 28, 1988).

Even if factoring agreements are concluded and their clients are not banks but enterprises, the unformed classical factoring in Ukraine results in mixed factoring agreements. This happens due to the weak development of current legislation. Upon terms of these agreements, factors attempt to add obligations on customers. And this kind of agreements does not correspond to factoring operations, and as a result, they may cause an enterprise's economic activity closure.

Thus, according to Part 1 of Article 1084 of the Civil Code of Ukraine, if according to the provisions of the factoring agreement, a factor finances a client by way of purchasing the monetary claim right from a client, a factor shall acquire the right for all the sums receivable from a debtor to perform the claim, and a client shall not be liable to a factor in case the sums received by him being less than the sum paid by a factor to a client. Part 2 of the mentioned Article provides that if the objective of cession of the monetary claim right to a factor is to ensure the client's performance of the obligation to a factor, the factor shall be obliged to submit a report to the client and to transfer a sum of money exceeding the 
client's debt secured by the cession of the monetary claim right, unless otherwise is stipulated by the factoring agreement. If the sum received by a factor from a debtor was less than the client's debt to a factor secured by the claim right, the client shall be obliged to pay the factor the remaining debt. Hence, Article 1084 of the Civil Code of Ukraine establishes the classic factoring contract in the first part: financing of accounts receivable is concluded without any caveat, and a client shall not be liable to a factor in case the sums received by him being less than the sum paid by a factor to a client. It is clear that signing by the bank of such an agreement obliges bank to sum up the pros and cons and to be as effective as possible in recovering accounts receivable. The second part of Article 1084 of the Civil Code of Ukraine describes a less risky for the factor type of factoring agreement. So, the lack of funds or the risk of non-payment relies on the client, not on the factor. However, the Civil Code of Ukraine clearly states the existence of a single condition for such a factoring agreement: there must be a certain initial obligation between the factor and the client (it may be, for example, a loan agreement). In this case, the factoring agreement serves as a guarantee for the loan agreement realization. And if the debtor under the factoring agreement will not pay to the factor or will pay them in less quantity, the bank has the right to demand the repay the debt from the client.

As lawyers indicate, banks often identify factoring with regression (reversible) with the kind of factoring provided in Part 2 of Article 1084 of the Civil Code of Ukraine. And in order to evade the maximum risks, banks impose on the client the obligation to pay the sum (that wasn't received) from the debtor, even when there are no grounds for this. There were a lot of cases when the factor insisted on the mixed factoring agreement with the conditions specific to the contract of bail. Thus, the agreement of the debtor's monetary claim to the factor was provided by a bail, and the guarantor was the client himself. But such an agreement cannot be considered as lawful. Thus, according to Part 1 of Article 553 of the Civil Code of Ukraine, a bail under a bailment agreement shall warrant to the debtor's creditor for the fulfilment of his obligation. The Civil Code of Ukraine does not specify any clear and exhaustive criteria a person (intending to become a surety) should correspond to. However, as the practice shows, the bail's essence as means of ensuring the fulfilment of the obligation is that the third party (the guarantor) undertakes to be responsible to the creditor for a violation of the obligation by the debtor. This third person, as a rule, is independent of the creditor and the debtor, at least formally. As for the case described above, there cannot exist "third person", moreover an independent one. As far as, the client under the factoring agreement is the direct participant in the main obligation, which is secured by bail. Therefore, based on the legal nature of the surety, the client cannot become a guarantor in this case. Since he/she is closely related with a factor and a debtor. And he/she is even far more interested in fulfilling debtor's duty than the debtor is. By imposing on the client additional obligations of suretyship, the bank does not take into account the legal nature of this type of the obligation at all. In addition, the client is in a very disadvantageous position. In this case, the amount of the money is taken into account, primarily. So, as a rule, advance financing for factoring is not executed for $100 \%$, but approximately $70-80 \%$ of the total amount of the claim rights' cession. While a surety is given for the debtor to fulfil his/her obligation to repay the debt in favour of the bank, the client undertakes to be responsible for failure to fulfil this obligation in the full amount of all monetary claims (100\%) (Soroka).

Thus, the legal constructs of factoring operations in domestic practice do not correspond to the economic essence of this type of financial activity. And it has long and powerful tendencies abroad. Particularly, according to the Factors Chain International Organization, economically developed countries, in 2015 had the classic factoring market estimated with enormous amounts: China - 406102 million euros, the United Kingdom - 350622 million euros, Italy 183004 million euros, the United States 95000 million euros. As example were taken counties that according to the World Bankin 2015 were among the top ten countries with the highest GDP. What concerns Ukraine, according to the National Commission for Regulation of Financial Services Markets, the number of factoring agreements in Ukraine in 2015 was 16.56 billion hryvnias or about 631.5 million euros. The share of classical factoring was only 5.6 billion hryvnias or 213.6 million euros (Sambirskyi).

In the classic factoring market in Ukraine, such companies as Arma Factoring, FC Factoring, Factor Plus, and Factoring Finance are represented. Among the banks, the most active in providing classic factoring services are 7 institutions - FUIB, Raiffeisen Bank Aval, UniCredit Bank, OTP Bank, Alfa-Bank, Pivdennyi Bank, Ukreximbank. Credit Agricole works exclusively with one client, the Auchan network (Sambirskyi).

\section{Conclusions of the study and prospects for further exploration in this direction}

Reasons preventing to construct the classic factoring market in Ukraine, aimed at the development of small and medium-sized businesses, have a complex nature. Not only are they related to the drawbacks of domestic legislation and practice of its application, but economic factors as well. Factoring companies have weak financial potential and no substantive financial amounts since accounts receivable are financed by companies at their own expense. Funds request from bank loans or other borrowed funds for these purposes decreases annually. Cheap loans or means of currency issuing for securities (such as bonds) 
are available abroad. Moreover, the important problem that impedes the development of the classical factoring market in Ukraine, the proper implementation by the law enforcement authorities of the decree on debt collection from the debtor. There is a possibility to avoid debt payment that produces the risk to the factor and makes the search for non-traditional ways of guaranteeing the restitution of funded accounts receivable.

\section{References:}

Levchenko N.M., Kravchenko H.V. (2009). Faktorynh yak instrument efektyvnoho upravlinnia debitorskoiu zaborhovanistiu. Ekonomichnyi prostir, № 23/2, pp. 242-251.

Matviichyk L.O., Holyk T.M. (2018). Sutnist ta rol faktorynhovykh posluh u bankivskomu sektori Ukrainy. Aktualni problemy sotsialno-ekonomichnykh system $\mathrm{v}$ umovakh transformatsiinoi ekonomiky: Zbirnyk naukovykh statei za materialamy IV Vseukrainskoi naukovo-praktychnoi konferentsii (12-13 kvitnia 2018 r.). Part 1. Dnipro: NMetAU, pp. 31-35.

Mineev A.D. (2014). Effektivnost faktoringovyih operatsiy kommercheskih bankov : dis. ... kand. ekon. nauk: 08.00.10. Moskva, $221 \mathrm{p}$.

Nederia L.V. (2014). Faktorynhovi operatsii: tekhnolohiia provedennia ta oblikovi protsedury. Sumy: Mriia-1 LTD; UABS, $320 \mathrm{p}$.

Bezklubyi I. (2005). Do pytannia pro yurydychnu pryrodu dohovoru faktorynhu. Pidpryiemnytstvo, hospodarstvo $i$ pravo, № 3, pp. 89-91.

Gasnikov K.D. (2005). Sravnitelnaya harakteristika dogovora finansirovaniya pod ustupku denezhnogo trebovaniya (faktoring) po pravu Rossii i Anglii: diss. ... kand. yurid. nauk: 12.00.03. Moskva, 214 p.

Zghama A.O. (2013). Pro faktorynh yak hospodarsko-pravovyi dohovir. Pravove zhyttia suchasnoi Ukrainy: materialy Mizhnar. nauk. konf. prof.-vykl. ta aspirant. skladu (m. Odesa, 16-17 travnia 2013 r.) / vidp. za vyp. V.M. Dromin ; NU "OYA". South region Center of NPR of Ukraine. Odessa: Phoenix, T. 2, pp. 739-749.

Tokunova A. (2011). Mistse faktorynhu v systemi prava Ukrainy. Pidpryiemnytstvo, hospodarstvo i pravo, № 1, pp. 114-117.

Chapichadze Ya.O. (2000). Dohovir faktorynhu: dys. ... kand. yuryd. nauk: 12.00.03. Kharkiv, 189 p.

Zavhorodnii V. (2005). Faktorynh: osoblyvosti deiakykh operatsii. Hlav. bukh. bezblankov otchetnosty, № 9, pp. 25-35.

Iuhas E.F., Popovych M.S. (2015). Ekonomichnyi zmist faktorynhu: Sutnist ta mistse v rynkovii ekonomitsi. Naukovyi visnyk Uzhhorodskoho natsionalnoho universytetu. Seriia: Mizhnarodni ekonomichni vidnosyny ta svitove hospodarstvo, Vypusk 1, pp. 89-95.

Commercial Code of Ukraine: Law of Ukraine No. 436-IV of January 16 (2003). Vidomosti Verkhovnoi Rady Ukrainy, No. 18, No. 19-20, No. 21-22. Art. 144.

The Civil Code of Ukraine: Law of Ukraine No. 435-IV of January 16 (2003). Vidomosti Verkhovnoi Rady Ukrainy, No. 40-44. Art. 356.

On Financial Services and State Regulation of Financial Services Markets: Law of Ukraine No. 2664-III dated July 12 (2001). Vidomosti Verkhovnoi Rady Ukrainy, No. 1, Art. 1.

On Banks and Banking: Law of Ukraine No. 2121-III dated December 7, (2000). Vidomosti Verkhovnoi Rady Ukrainy, No. 5-6, Art. 30.

Ruda O.L. Faktorynh: osnovni perevahy ta nedoliky pered kredytuvanniam. Retrieved from: http://www.rusnauka.com/2_KAND_2008/Economics/26074.doc.htm (date: 10/06/2018)

Sambirskyi M. Chomu v Ukraini ne rozvyvaietsia klasychnyi faktorynh? Retrieved from: http://blog.liga.net/ user/msambirskiy/article/24424 (date: 10/06/2018)

Palchuk O.I. (2010). Faktorynh yak spetsyfichna finansova posluha. Visnyk Natsionalnoho universytetu «Lvivska politekhnika». Ser.: Menedzhment ta pidpryiemnytstvo v Ukraini: etapy stanovlennia i problemy rozvytku, No 682, pp. 168-173.

Sambirskyi M. Stan ta perspektyvy rozvytku klasychnoho faktorynhu v Ukraini. Retrieved from: http://ukrfactor.com/novina/?n=26 (date: 10/06/2018)

About Ukraine's accession to the UNIDROIT Convention on International Factoring: Law of Ukraine No. 3302-IV dated 11th of May (2006). Vidomosti Verkhovnoi Rady Ukrainy, No. 16, Art. 139.

About International Factoring: UNIDROIT Convention of May 28, 1988. Retrieved from: http://zakon5.rada.gov.ua/laws/show/995_210 (date: 10/06/2018)

Soroka A. Faktorynh: «shtuchne dykhannia» chy «evtanaziia» dlia biznesu? Retrieved from: http://blog.liga.net/ user/asoroka/article/18548\#fb-root (date: 10/06/2018) 